The Origin of the World 
BOOKS BY PIERRE MICHON IN ENGLISH

Small Lives (Vies minuscules, 1984)

Masters and Servants (Maîtres et serviteurs, 1990)

Rimband the Son (Rimband le fils, 199I)

Winter Mythologies and Abbots (Mythologies d'hiver, 1997; Abbés, 2002)

The Eleven (Les Onze, 2009) 


\title{
The Origin of the World
}

\section{PIERRE MICHON}

TRANSLATED AND WITH A NEW INTRODUCTION BY WYATT MASON

\author{
WITH AN AFTERWORD BY \\ ROGER SHATTUCK
}

YALE UNIVERSITY PRESS — NEW HAVEN \& LONDON

\section{A MARGELLOS}


The Margellos World Republic of Letters is dedicated to making literary works from around the globe available in English through translation. It brings to the English-speaking world the work of leading poets, novelists, essayists, philosophers, and playwrights from Europe, Latin America, Africa, Asia, and the Middle East to stimulate international discourse and creative exchange.

First Yale University Press edition 2013.

First published in English by Mercury House in 2002.

Originally published as La Grande Beune. (C) Éditions Verdier, 1996.

Translation copyright (C) 2002 by Wyatt Mason.

Introduction copyright (C) 2013 by Wyatt Mason.

Afterword originally published, in slightly different form, as "Notes from Underground," Harper's Magazine, June 2002. Copyright (C) 2002 by the Estate of Roger Shattuck, by permission of the Jennifer Lyons Literary Agency, LLC.

A note on the title: Michon's working title was L'Origine du monde. Shortly prior to publication, however, another work came out so named, thus he chose La Grande Beune. For the English edition, the author prefers that his original title be preserved.

This work, published as part of a program of aid for publication, received support from the French Ministry of Foreign Affairs and the Cultural Services of the French Embassy in the United States. Cet ouvrage, publié dans le cadre d'un programme, d'aide à la publication bénéficie $d u$ soutien du Ministère des Affaires étrangères et du Service Culturel de l'Ambassade de France aux ÉtatsUnis.

All rights reserved.

This book may not be reproduced, in whole or in part, including illustrations, in any form (beyond that copying permitted by Sections 107 and 108 of the U.S. Copyright Law and except by reviewers for the public press), without written permission from the publishers.

Yale University Press books may be purchased in quantity for educational, business, or promotional use. For information, please e-mail sales.press@yale.edu (U.S. office) or sales@yaleup.co .uk (U.K. office).

Book design by Mark Barry of sübata.

Printed in the United States of America.

Library of Congress Control Number: 2013939964

ISBN 978-0-300-I8070-I (pbk: alk. paper)

A catalogue record for this book is available from the British Library.

I0 987654321 